\title{
Implikasi Penyitaan Barang-barang Milik Negara dan Konsekuensi Hukumnya
}

\author{
Mohammad Effendi \\ Universitas Lambung Mangkurat Banjarmasin
}

Legal problems related to confiscation process of state properties should become a common concern, especially in the era of administrative court. Execution of administrative court decisions is commonly accompanied by an order to pay damages or compensation. Regarding public bodies, such as Central and Regional Governments, together with their staffs, provision of damages and compensation is allocated in the National and Regional Budgets. Therefore, its implementation is relatively easier, and its problem relates only with administrative matters, different from other public bodies, such as state owned companies that are also included in executive tasks. This article recommends that a more detail regulation be important in order to implement administrative court decisions easier.

Keywords: confiscation, public bodies, administrative court, decision.

spek-aspek penyitaan dalam kaiatan
yang melibatkan pengadilan dibedakan
antara penyitaaan dalam perkara perdata
dan penyitaan dalam hubungannya dengan
tindak pidana. Pengertian penyitaan dalam
hubungannya dengan perkara perdata
adalah tindakan hukum pengadilan
mendahului pokok perkara atau mendahului
putusan. (Harahap, 1990 : 5 )
Pengaturan mengenai penyitaaan ini
dapat ditemukan dalam pasal 227 jo pasal
261 jo pasal 206 RBg. Dari pengertian
penyitaan tersebut di atas, dapatlah
dimengerti bahwa tindakan penyitaaan
merupakan tindakan hukum yang
eksepsional, sehingga penerapannya harus
dilakukan dengan segala pertimbangan dan
kehati-hatian. la harus didukung dengan
fakta-fakta dan bukti-bukti yang meyakinkan
agar tindakan penyitaan itu tidak
menimbulkan kerugian terhadap pihak yang
terkena penyitaan. Dalam hukum acara perdata secara umum dikenal istilah sita jaminan - conservatoir beslag dan revindicatoir beslag serta sita eksekusi. Sita jaminan adalah penyitaaan terhadap barang tergugat atau barang yang disengketakan untuk dijadikan jaminan sementara proses pemeriksaan perkara sedang berlangsung. Sedangkan revindicatoir beslag adalah penyitaan terhadap barang milik penggugat sendiri yang berada dalam kekuasaan tergugat.

Selama dalam proses penyitaan, tergugat dilarang untuk menjual, menghibahkan atau memindah tangankan barang sitaan kepada siapapun. Namun demikian dalam sita jaminan ada beberapa prinsip penting yakni:

- Hak atas benda sitaan tetap dimiliki oleh tergugat.

- Penguasaan benda sitaan tetap dipegang oleh tergugat.

- Semata-mata sebagai jaminan (Harahap, 1990 : 5) 
Implikasi Penyitaan Barang-barang Milik Negara dan...; Mohammad Effendi

Revindicatoir beslag adalah tindakan penyitaan yang dikarenaka barang yang dikuasai tergugat itu diperoleh melalui cara yang tida sah, atau dengan cara melawan hukum dan objeknya terbatas ada benda bergerak. Sedangkan sita eksekusi adalah penyitaan untuk tujuan dijual atau dilelang.

Selanjutnya jika diikuti rumusan penyitaan dalam perkara pidana, dapat dilihat dalam ketentuan pasal 1 butir 16 KUHAP yang memberikan definsi sebagai berikut:

"Penyitaan adalah serangkaian tindakan penyitaan untuk mengambil alih atau menyimpan dibawah pengawasannya benda bergerak atau tidak bergerak, berwujud atau tidak berwujud untuk kepentingan pembukti dalam penyidikan, penuntutan dan peradilan".

Dari pengertian di atas dapat dipahami bahwa tindakan penyitaan langsung berkaitan dengan hak asasi manusia yang pokok, yaitu merampas penguasaan atas milik orang lain. Dalam universal Declaration of Human Rights disebutkan pada pasal 17 ayat (10 Every one has the to own property aloe as well as in association with others (setiap orang berhak mempunyai milik baik sendiri maupun bersama-sama dengan orang lain), dan dalam ayat (2)nya disebutkan No one shall be arbitrarily deprived of his property (seseorang tidak boleh dirampas miliknya dengan semena-mena).

Mengingat hal itulah maka penyitaan yang dilakukan guna kepentingan pemeriksaan pidana haruslah mengikuti tata cara dan prosedur yang telah ditetapkan oleh undang-undang. Menurut ketentuan pasal 38 ayat (1) KUHAP, penyitaan bisa dilakuka dengan izin dari Ketua Pengadilan Negeri setempat. Ketentuan ini mendapat pengecualian sebagaiman diatur dalam ayat
(2); dalam keadaan yang sangat perlu dan mendesak bilamana penyidik harus segera bertindak dan tidak mungkin untuk mendapatkan surat izin terlebh dahulu, penyidik dapat melakukan penyitaan hanya atas benda bergerak dan untuk itu wajib segera melaporkan kepada Ketua Pengadilan Negeri setempat guna mendapat persetujuannya.

Dari uraian di atas diketahui adanya sedikit perbedaan antara penyitaan dalam perkara perdata dengan penyitaan dalam perkara pidana. Dalam perkara perdata, penyitaan dilakukan atas perintah Ketua Majelis Hakim yang memeriksa perkara yang bersangkutan. Dalam hal sita eksekusi perintah penyitaan dibuat oleh Ketua Pengadilan. Sebaliknya dalam perkara pidana, penyitaan dilakukan oleh petugas penyidik, Ketua Pengadilan Negeri setempat berwenang mengeluarkan izin penyitaannya.

Permasalahannya sekarang adalah: bisakah Pengadilan melakukan penyitaan terhadap barang-barang milik negara. Untuk menjawab persoalan ini, kita harus kembali kepada kedudukan negara sebagai organsasi kekuasaan yang bisa bertindak dalam kerangka publik dan privat seperti telah diuraikan sebelumnya. Dalam hal pemerintah bertindak dalam kapasitasnya sebagai Badan Hukum Publik yang melakukan tindaka keperdataan, maka ia harus tunduk kepada hukum positif biasa. Apabila pemerintah Ialai dalam melaksanakan hak dan kewajibannya, misalnya adanya kelalaian dalam membayar harga barang yang dibeli berdasarkan kontrak yang sudah disepakati, atau lalai dalam memberikan ganti kerugian kepada warga yang kepentingannya terganggu akibat perbuatan pemerintah, maka pemerintah bisa dituntut melalui pengadilan. 
Hakim yang memeriksa dan mengadili perkara itu mendudukkan posisi pemerintah sejajar dengan penggugat. Secara yuridis formal, pada dasarnya hakim bisa memerintahkan penyitaan terhadap barangbarang milik pemerintah dalam rangka memenuhi tuntutan penggugat. Namun demikian hakim tidak boleh memerintahkan penyitaan terhadap barang-barang milik negara (pemerintah) yang sudah menjadi milik umum (publik domein). Sebab, hal ini akan sangat mengganggu kepentingan yang lebih umum. Jadi penyitaan hanya terbatas kepada barang milik pribadi pemerintah.

Akan tetapi jika dilihat dari tujuan tindakan hukum penyitaan, yakni untuk menjamin agar tuntutan penggugat nantinya tidak sia-sia apabila keputusannya sudah mendapat kekuatan hukum yang tetap, maka dalam kaitan dengan pemerintah, tindakan penyitaan itu sebenarnya tidak diperlukan. Hal ini mengingat kedudukan pemerintah selaku penyelenggara kekuasaan tentu setiap saat mempunyai kemampuan untuk memenuhi segala kewajibannya, meskipun harus melalui prosedur administratif tertentu.

Dalam kasus Kedongombo, misalnya: berdasarkan putusan Mahkamah Agung tertanggal 28 Juli 1993, Majelis Hakim Agung telah menghukum tergugat (Gubernur KDH TK I Jawa Tengah) untuk membayar ganti rugi materiil / tanah sebesar $\mathrm{Rp}$. 50.000,per meter serta membayar ganti rugi immateriil sebesar 2 milyar. Sayangnya putusan ini kemudian dibatalkan oleh Mahkamah Agung ketika memeriksa peninjauan kembali yang dituangkan dalam putusan tertanggal 29 Oktober 1994 (Republika, 1994 : 8 Nopember).

Sekiranya Keputusan Hakim Agung terdahulu tidak dibatalkan dan eksekusi bisa dilaksanakan, maka Pengadilan tidak bisa menyita proyek yang menjadi sebab timbulnya sengketa. Sebabnya antara lain proyek Kedongombo itu sendiri bukan merupakan milik pribadi pemerintah, tetapi sudah menjadi milik publik. Yang bisa dilakukan pemerintah sekiranya eksekusi dilaksanakan adalah menyediakan dana ganti rugi melalui APBN atau ABPD.

Perlu pula dikemukakan disini, bahwa penyitaan barang milik negara dilarang secara umum akibat perbuatan pejabat pemerintah dalam kapasitas pribadi. Misalnya seorang pejabat pemerintah yang terlibat dalam utang-piutang dan kemudian digugat oleh kreditur di Pengadilan dan sekaligus meminta untuk dilakukan sita jaminan terhadap rumah yang didiami tergugat. Padahal rumah yang ditempati tergugat (debitur) itu adalah rumah dinas. Hakim tidak mungkin membuat atau menyusun alasan yang bagaimanapun untuk mengabsahkan pembebanan sita jaminan terhadap rumah dinas tersebut atas nama kepentingan penghuninya. (Harahap, 1990: 157). Larangan ini berlaku juga pada barang milik ketiga yang tidak terkait dengan perkara pihak-pihak.

Dalam perkara pidana kemungkinan penyitaan barang milik negara bisa pula terjadi, sitidaknya dalam dua hal. Pertama, penyitaan terhadap barang milik negara murni, dan kedua, terhadap barang yang mungkin akan menjadi milik negara. Penyitaan terhadap barang milik negara murni bisa terjadi dalam kasus pencurian. seorang atau sekelompok orang yang melakukan pencurian terhadap benda-benda bersejarah di suatu Museum, kemudian tertangkap oleh petugas. Untuk kepentingan penyidikan, penuntutan dan atau pembuktian di sidang pengadilan, petugas tadi berwenang menyita barang-barang yang dicuri tadi yang notabene adalah barang 
Implikasi Penyitaan Barang-barang Milik Negara dan...; Mohammad Effendi

milik negara. Penyitaan itu tentu saja harus tetap mengikuti prosedur yang diatur dalam KUHAP yakni adanya izin dan atau persetujuan ketua Pengadilan Negeri setempat. Segera setelah proses penyidikan, penuntutan dan pembuktian telah dianggap selesai, barang-barang tadi dikembalikan kepada negara.

Mengenai penyitaan terhadap barang yang mungkin akan menjadi milik negara, bisa terjadi misalnya dalam kasus tindak pidana penyelundupan. Berkaitan dengan tindak pidana penyelundupan ini dapat dilihat ketentuan yang termuat dalam Keputusan Menteri Keuangan Nomor : 268 / KM.01/1982 tentang Ketentuan Pemberian Uang Ganjaran kepada Mereka yang telah memberikan jasa dalam penyelesaian tindak pidana penyelundupan jo surat edaran Menteri Keuangan tertanggal 15 Juni 1984 Nomor : S-183/MK.1/1984 tentang tata laksana pemberian ganjaran.

Dikeluarkannya ketentuan di atas salah satu pertimbangannya adalah dalam rangka mengamankan kebijaksanaan pemerintah terutama dibidang fiskal. Sebab, dengan adanya tindak penyelundupan, maka negara akan sangat dirugikan terutama dibidang fiskal dan bisa pula memberi pengaruh terhadap pengembangan ekonomi nasional.

Pada dasarnya kedua ketentuan di atas membedakan antara penyitaan yang kemudian ditindak lanjuti dengan pelelangan di muka umum, dan penyitaan yang kemudian diikuti dengan pemusnahan. Apabila barang selundupan itu oleh pengadilan harus diserahkan kepada negara, maka barang itu kemudian dilelang dan hasil pelelangan itu dibagi sebagai berikut:

- $\quad 50 \%$ untuk negara

- $\quad 50 \%$ dibagi antara:
- $\quad 30 \%$ untuk mereka yang turut serta dalam proses penangkapan.

- $\quad 12,5 \%$ kepada mereka yang secara nyata menyidik dan menyelesaikan perkara sehingga berkas perkara dapat diajukan ke pengadilan

- $\quad 7,5 \%$ kepada dana operasional pemberantasan penyelundupan Kantor Pusat Direktorat Jenderal Bea dan Cukai.

Sekarang ini kemungkinan adanya tindakan penyitaan terhadap barang negara tidak saja dalam perkara peradata dan pidana, tetapi bisa pula dalam sengketa administratif, yakni dengan diterapkannya undang-undang No. 5 tahun 1986 tentang Peradilan Tata Usaha Negara. Peradilan ini secara khusus akan memeriksa dan mengadili konflik kepentingan antara pemerintah dengan seseorang atau Badan Hukum Perdata akibat dikeluarkannya keputusan (Beschikking) oleh Badan atau Pejabat Tata Usaha Negara.

Menurut Ketentuan pasal 1 ayat (3) "Keputusan Tata Usaha Negara adalah suatu penetapan tertulis yang dikeluarkan oleh Badan atau Pejabat Tata Usaha Negara yang berisi tindakan hukum Tata Usaha Negara yang berdasarkan peraturan perundangundangan yang berlaku, yang bersifat konkret, individual, dan final yang menimbulkan akibat hukum bagi seseorang atau badan hukum perdata".

Mengingat inti sengketa PTUN ini adalah Keputusan Badan atau Pejabat TUN, maka dalam hal gugatan penggugat dikabulkan, maka menurut ketentuan pasal 97 ayat (9) disebutkan kewajiban yang harus dipenuhi oleh Badan atau Pejbata TUN, yakni:

a. Pencabutan Keputusan TUN yang bersangkutan. 
b. Pencabutan Keputusan TUN yang bersangkutan dan menerbitkan Keputusan TUN yang baru, atau

c. Penerbitan Keputusan TUN dalam hal gugatan berkaitan dengan permohonan yang ditolak atau dianggap ditolak.

Namun demikian bisa pula putusan Pengadilan Tata Usaha Negara itu disertai dengan pembayaran ganti rugi yang harus dibayar oleh Badan atau Pejabat TUN. Mengenai ganti rugi ini diatur dalam pasla 120 yang kemudian dijabarkan secara lebih teknis dalam peraturan Pemerintah NO. 43 tahun 1991. Menurut Peraturan Pemerintah ini ada istilah ganti rugi dan kompensasi. Yang dimaksud ganti rugi adalah pembayaran sejumlah uang kepada orang atau badan hukum perdata atas beban Badan Tata Usaha Negera berdasarkan putusan Pengadilan Tata Usaha Negara karena adanya kerugian materiil yang diderita oleh penggugat (Vide pasal 1 ayat 1). Sedangkan kompensasi adalah pembayaran sejumlah uang kepada orang atas beban Badan Tata Usaha Negara oleh karena putusan Pengadilan Tata Usaha Negara di bidang kepegawian tidak dapat atau sempurna dilaksanakan oleh Badan Tata Usaha Negara (vide pasal 1 ayat 2).

Beban pembayaran ganti rugi dan kompensasi ini sumbernya dibagi kepada 3 komponen (pasal 2):

(1) Ganti Rugi yang menjadi tanggung jawab Badan Tata Usaha Negara Pusat, dibebankan pada Anggaran Pendapatan dan Belanja Negara (APBN).

(2) Ganti Rugi yang menjadi tanggung jawab Badan Tata Usaha Negara Daerah, dibebankan pada Anggaran Pendapatan dan Belanja Negara Daerah (APBD)

(3) Ganti Rugi yang menjadi tanggung jawab Badan Tata Usaha Negara di luar ketentuan ayat (1) dan ayat (2), menjadi beban keuangan yang dikelola oleh Badan itu sendiri.

Selanjutanya PP. No. 43 tahun 1991 mengatur pula batas minimal besarnya ganti rugi dan kompensasi. Untuk ganti rugi ditetapkan sedikitnya Rp. 205.000,- (Dua ratus lima puluh ribu rupiah), dan paling banyak Rp. 5.000.000 (lima juta rupiah), dengan memperhatikan keadaan yang nyata (vide pasal 3). Ganti rugi ini bersifat tetap, meskipun ada tenggang waktu antara ditetapkannya ganti rugi itu oleh Pengadilan dengan waktu pembayarannya. Mengenai besarnya uang kompenasasi ditetapkan paling sedikit Rp. 100.000,- (seratus ribu rupiah) dan paling banyak Rp. 2.000.000,(dua juga rupiah), dengan memperhatikan keadaan yang nyata. Sama halnya dengan ketentuan ganti rugi, besarnya kompensasi juga bersifat tetap meskipun ada tenggang waktu antara putusan Pengadilan dengan pembayaran kompensasi (vide pasal 14).

Dengan adanya kewajiban Pemerintah untuk membayar sejumlah ganti rugi dan kompensasi dalam bentuk uang, pada dasarnya Hakim PTUN berwenang untuk melakukan penyitaan sebagai jaminan dilaksanakannya putusan pengadilan terhadap barang-barang milik negara. Kewenangan ini bersumber dari adanya kebebasan hakim sebagai asas negara hukum. Akan tetapi prosedur pelaksanaan putusan pengadilan administratif tidak sama dengan ketentuan hukum secara perdata yang diatur dalam HIR dan RBg.

Menurut ketentuan pasal 116 ayat (1) s/d ayat (6) disebutkan bahwa setelah keputusan pengadilan mempunyai kekuatan hukum yang tetap, maka selambatlambatnya 14 hari disampaikan kepada para pihak. Dalam hal tergugat tidak melaksanakan kewajiban seperti disebutkan dalam keputusan, maka 
Implikasi Penyitaan Barang-barang Milik Negara dan...; Mohammad Effendi

penggugat memohon kepada pengadilan agar tergugat segera melaksanakan kewajibannya. Jika tergugat tidak juga melaksanakan isi keputusan, ketua pengadilan mengirim surat kepada atasan tergugat sesuai dengan jenjang jabatan agar bawahannya mentaati isi putusan pengadilan. Apabila tergugat masih juga tidak melaksanakan, maka pengadilan meminta kepada Presiden sebagai pemegang kekuasaan pemerintah tertinggi agar memerintahkan aparatnya itu mematuhi isi putusan pengadilan.

Undang-undang No. 5 tahun 1986 tidak lagi mengatur lebih lanjut bagaimana mekanisme selanjutnya tentang nasib putusan Pengadilan Tata Usaha Negara. Secara teoritis akademis hanya disebutkan bahwa sebagai pemerintah yang baik sudah seharusnyalah mematuhi dan menjunjung tinggi semua keputusan pengadilan untuk menjaga wibawa hukum dan umumnya dan wibawa serta kepercayaan masyarakat terhadap pemerintah pada khususnya.

\section{Penutup}

Masalah hukum yang berkaitan dengan proses penyitaan barang-barang milik negara pada masa mendatang semakin perlu mendapat perhatian bersama, terutama dalam era Peradilan Tata Usaha Negara. Pada akhir tulisan ini telah disebutkan bahwa eksekusi putusan PTUN sangat tergantung dengan pihak eksekutif dalam rangka menghormati eksistensi peradilan. Terlebih lagi jika putusan PTUN tersebut disertai dengan perintah pembayaran ganti rugi atau kompensasi.

Untuk badan-badan Publik seperti pemerintah pusat dan atau pemerintah daerah beserta segenap jajarannya, penyediaan dana ganti rugi dan kompensasi dialokasikan dalam APBN/APBD. Dengan demikian pelaksanaanya relatif lebih mudah dan persoalannya hanya berkaitan dengan teknis administratif. Berbeda halnya dengan Badan Publik lain seperti BUMN yang juga termasuk kategori melaksanakan tugas eksekutif, maka perlu ada pengaturan yang lebih rinci agar memudahkan pelaksanaan putusan PTUN.

\section{Daftar Pustaka}

AP. Palindungan,1991. Komentar atas Undang-Undang Pokok Agraria, Bandung:Mandar Maju.

Amrah Muslimin,1985. Beberapa Asas dan Pengertian Pokok tentang Administrasi dan Hukum Administrasi. Bandung:Alumni.

Harian Umum Republika, 1990. Permasalahan dan Penerapan Sita Jaminan Coservatoir Beslag, Bandung:Pustaka.

Philipus MI Hadjon, 1987.Perlindungan Hukum bagi Rakyat di Indonesia, Surabaya:Bina IImu.

(Penyunting), Pengantar Hukum Perizinan, Yuridika, Surabaya, 1993.

Philipus MI Hadjon,dkk,1993. Pengantar Hukum Administrasi Indonesia, Yogyakarta: Gadjah Mada University Press.

Sjachran Basah, 1989. Eksistensi dan Tolok Ukur Badan Peradilan Administrasi di Indonesia,Bandung:Alumni, cet. V.

Sjachran Basah, 1992.Perlindungan Hukum terhadap Sikap Tindak Administrasi Negara,Bandung:Alumni. 
UNISIA, Vol. XXX No. 66 Desember 2007

Walter Bagehot,1992. The English Constitution: The Cabinet dalam Parlementary Versus Presidential Geverment (edited by Arend Lihphart) Oxford: University Press.

Utrecht, E., 1964.Pengantar Hukum Administrasi Negara Indonesia, Jakarta:Ichtiar.
Yahya Harahap,1990. Permasalahan dan Penerapan Sita Jaminan Coservatori Beslag,Bandung: Pustaka.

$\square \square \square$ 